\title{
PENGARUH EDUKASI TERHADAP KEMAMPUAN KELUARGA DALAM PERAWATAN STOMA PADA PASIEN YANG MENGALAMI KOLOSTOMI DI RSUP. H. ADAM MALIK MEDAN TAHUN 2021
}

\author{
Suriani Ginting, S.Kep,Ns,M.Kep \\ Jurusan Keperawatan Poltekkes Kemenkes Medan \\ Email :surianiginting68@gmail.com
}

\begin{abstract}
The family can be involved in the patient's stoma care, so the family is expected to be able to monitor and help the patient to achieve self-care. Stoma is a bowel hole that appears on the surface of the abdomen in the reddish mucosa form. One way to increase family knowledge is by providing education. Education is an intervention that can help patients and families to maintain stoma health with appropriate care. The purpose of this study was to determine the effect of education on the ability of families on the treatment of stomas in patients undergoing colostomy at the General Hospital H. Adam Malik Medan. This research is a quantitative analytic study with a quasi-experimental research design by the pre and post test treatment groups. The population in this study were 71 people. A sample of 42 respondents representing the families of patients who had a colostomy at the General Hospital H. Adam Malik Medan. In this study, the analysis used is the Willcoxon Signed Rank Test, with $p$ value $<0.05$. The average value of ability of the family before being educated was 2.00 and a range of 2 to 3 . This shows that the ability of familieswas less in caring for stoma while the ability after being educated was of 3.00 and a range of 3 to 3 . Its means that the family was able to perform stoma care for his family who had a colostomy. From the differences in the median value and probability was $p<0.05$. It can be concluded that education has an effect on increasing the ability of families in stoma care in patients undergoing colostomy.
\end{abstract}

Keywords : Education, Stoma Care, Family

\begin{abstract}
ABSTRAK
Keluarga dapat terlibat dalam perawatan stoma pasien, sehingga keluarga diharapkan dapat memantau dan membantu pasien untuk mencapai self care-nya. Stoma merupakan lubang usus yang muncul dipermukaan abdomen yang berupa mukosa kemerahan. Salah satu cara untuk meningkatkan pengetahuan keluarga adalah dengan pemberian edukasi. Edukasi merupakan suatu intervensi yang dapat membantu pasien dan keluarga untuk memelihara kesehatan stoma dengan perawatan yang tepat. Tujuan dari penelitian ini adalah untuk mengetahui pengaruh edukasi terhadap kemampuan keluarga dalam perawatan stoma pada pasien yang mengalami kolostomi di RSUP. H. Adam Malik Medan. Jenis penelitian ini adalah penelitian analitik yang bersifat kuantitatif dengan desain penelitian quasi experiment. Rancangan penelitian adanya kelompok perlakuan pre dan post test. Populasi dalam penelitian ini sebanyak 71 orang. Sampel sebanyak 42 responden yaitu yang mewakili keluarga pasien yang mengalami kolostomi di RSUP. H. Adam Malik Medan. Dalam penelitian ini, analisis yang digunakan adalah uji Willcoxon Signed Rank Test, dengan nilai $\mathrm{p}=0.000(\mathrm{p}<0.05)$ yang artinya bahwa ada pengaruh edukasi terhadap kemampuan keluarga dalam perawatan stoma. Kemampuan keluarga sebelum diberi edukasi rata-rata nilai 2,00 dan rentang 2 sampai 3, hal ini menunjukkan kemampuan keluarga kurang dalam merawat stoma sedangkan kemampuan setelah diberi edukasi ratarata nilai 3,00 dan rentang 3 sampai 3, hal ini berarti bahwa keluarga sudah mampu melakukan perawatan stoma pada keluarganya yang mengalami kolostomi. Dari adanya perbedaan nilai median dan probabilitas $(\mathrm{p})<0,05$ dapat disimpulkan bahwa edukasi berpengaruh dalam peningkatan kemampuan keluarga dalam perawatan stoma pada pasien yang mengalami kolostomi.
\end{abstract}


Kata Kunci : Edukasi, Perawatan Stoma, Keluarga

\section{PENDAHULUAN}

\section{Latar Belakang}

Kolostomi biasanya disebabkan oleh kanker kolorektal, pecahnya divertikulitis, perforasi usus dan penyakit atau kerusakan sumsum tulang belakang sehingga tidak adanya kontrol (Kalibjian,2013). Dari beberapa penyebab kolostomi, penyebab tersering menurut Indonesian Ostomy Association/ NOA(2010),adalah kanker kolorektal. Kanker kolorektal merupakan penyakit keganasan yang menyerang usus besar (Manggarsari, 2013). Kanker kolorektal merupakan penyakit ketiga terbanyak di dunia dengan jumlah penderita baru pada tahun 2015 diperkirakan mencapai 132.700 orang (Siegelet al. 2015). Sementara di Amerika kanker kolorektal diperkirakan setiap tahunnya ada 150.000 kasus. MenurutWorld Health Organization/ WHO (2008), menyatakan bahwa kanker kolorektal merupakan penyebabtersering ketiga kanker yang terjadi padapria dan penyebab tersering kedua kankeryang terjadi pada wanita di seluruh duniapada tahun 2008. Meningkatnya jumlah penderita kanker kolorektal juga akan meningkatkan jumlah penderita kolostomi.

Kolostomi merupakan pembuatan lubang sementara atau permanen dari usus besar melalui dinding perut dengan tindakan bedah bila jalan ke anus tidak bisa berfungsi, dengan cara pengalihan aliran feses dari kolon karena gangguan fungsi anus (Suratun \& Lusianah, 2018). Lubang kolostomi yang muncul di permukaan/dinding abdomen yang berwarna kemerahan disebut stoma. Pembentukan kolostomi dapat dilakukan secara permanen atau sementara tergantung tujuan dilakukan operasi (Murwani, 2009). Pasien dengan pemasangan kolostomi disertai dengan prosedur tindakan laparotomi. Luka laparotomi sangat beresiko mengalami infeksi karena letaknya yang bersebelahan dengan lubang stoma yang kemungkinan banyak mengeluarkan feses yang dapat mengkontaminasi luka (Murwani, 2009). Komplikasi kolostomi bisa terjadi disepanjang hidup penderita walaupun secara umum komplikasi sering terjadi dalam lima tahun pertama sejak pembentukan kolostomi (Jordan \& Cristian, 2013).
Berdasarkan penelitian yang dilakukan oleh Lyonet al. (dalam Desvin,2014) terhadap dari 325 responden pengguna kantong stoma, menemukan 69,3\% penderita melaporkan adanya masalah kulit yaitu dermatosis termasuk reaksi iritasi, terutama dari kebocoran urin atau tinja (42\%), penyakit kulit yang sudah ada terutama psoriasis, dermatitis seborhoik dan eksim (20\%), infeksi (6\%), dermatitis kontak alergi $(0,7 \%)$ dan pyoderma gangrenosum $(0,6 \%$ kejadian tahunan). Masalah-masalah pada stoma kolostomi terkait dengan perawatan dapat dicegah dengan perawatan stoma yang tepat. Namun berdasarkan penelitian Herlufsenet al. (2006) terhadap 199 penderita stoma permanen, didapatkan hasil bahwa $77 \%$ penderita terdiagnosa ada masalah pada kulit sekeliling stoma (skin peristomal) karena kontak kulit dengan feses, 38\% penderita mengetahui bahwa mereka mengalami gangguan kulit sedangkan $80 \%$ penderita tidak menyadari adanya masalah pada kulit karena kurangnya pengetahuan tentang permasalahan mereka, sehingga mereka tidak berupaya untuk mencari bantuan tenaga kesehatan profesional.

Menurut Friedman (dalam Setiawan \& Dermawan, 2008), salah satu fungsi keluarga adalah fungsi pemenuhan (perawatan/pemeliharaan) kesehatan yang merupakan fungsi keluarga untuk mencegah terjadinya masalah kesehatan dan merawat anggota keluarga yang mengalami masalah kesehatan. Tujuan dari fungsi ini adalah untuk mengetahui sejauh mana kemampuan keluarga dalam merawat anggota keluarga yang sakit (Suprajitno, 2004). Berkembangnya kemampuan seseorang terjadi melalui tahapan tertentu, yang dimulai dari pembentukan pengetahuan, sikap, sampai dimilikinya keterampilan baru (Sulihaet al. 2001).

Keluarga yang sangat berperan harus diajarkan bagaimana cara mengelola kolostomi sejak awal pembentukan yaitu ketika mereka masih di rumah sakit. Sehingga ketika sudah meninggalkan rumah sakit keluarga sudah mampu melakukan perawatan kolostomi secara mandiri (Burch, 2013). Hal mendasar yang harus diketahui keluarga tentang perawatan kolostomi 4 menurut Truven Health 
Analitic (2015), adalah meliputi penggantian dan pengosongan kantong kolostomi, perawatan kulit sekeliling kolostomi serta pengelolaan diet untuk mencegah timbulnya gas, bau, diare atau konstipasi pada kolostomi. Pengetahuan keluarga tentang perawatan kolostomi akan berpengaruh terhadap kejadian komplikasi post kolostomi.

Salah satu cara untuk meningkatkan pengetahuan keluarga adalah dengan pemberian edukasi. Edukasi keluarga merupakan bagian dari asuhan keperawatan dengan memberikan pendidikan kesehatan yang terintegrasi yang berpusat pada masalah pasien (Potteret al. 2013). Pendidikan kesehatan merupakan salah satu pilar penatalaksanaan perawatan luka. Melalui pendidikan kesehatan secara terencana,individu,kelompok dan masyarakat dapat lebih patuh dalam penatalaksanaan perawatan luka sehingga mengurangi terjadinya komplikasi disamping upaya penatalaksanaan yang lainnya.

Pemberian edukasi dilakukan oleh tenaga kesehatan profesional dengan melibatkan keluarga secara aktif dalam mengatasi permasalahan kesehatan yang dihadapi pasien. Program dan strategi edukasi kesehatan yang efektif dapat menyebabkan hasil kesehatan yang lebih baik, khususnya membantu keluarga untuk mendapatkan lebih banyak pengetahuan dan keterampilan (Glanzet al. (dalam Maliniet al. 2015).

\section{METODE PENELITIAN}

Jenis dan Desain Penelitian

Penelitian ini merupakan penelitian kuantitatif yaitu penelitian yang banyak menggunakan angka, mulai dari pengumpulan data, penafsiran terhadap data tersebut, serta penampilan dari hasilnya (Sugiyono,2013). Penelitian ini menggunakan desain penelitian quasi eksperiment dan dengan rancangan penelitian one group pre and post test design yangbertujuan untuk mengungkapkan kemungkinan adanya pengaruh pengetahuanyang dimiliki keluarga terhadap kemampuan keluarga dalam perawatan stomapada pasien kolostomi di RSUP H. Adam Malik Medan.

\section{Populasi, Sampel, Teknik Sampling}

Populasi dalam penelitian ini adalah seluruh pasien kolostomi dan sedang menjalani rawat inap dan rawat jalan di RSUP. H. Adam Malik Medan pada bulan Januari 2021. Populasi penelitian dalam 1 tahun terakhir yaitu tahun 2020 adalah sebanyak 71 orang.
Sampel dalam penelitian ini adalah yang dianggap mewakili seluruh populasi dengan kriteria inklusi yaitu 42 responden dengan teknik sampling yang digunakan adalah purposive sampling yaitu pemilihan yang sesuai dengan yang dikehendaki, yang didasarkan pada suatu pertimbangan tertentu yang dibuat sendiri oleh peneliti berdasarkan ciri atau sifatsifat populasi (Hidayat ,2007).

\section{Analisa Data}

a. Analisa Univariat bertujuan untuk menjelaskan atau mendeskripsikan karakteristik setiap variabel penelitian, bentuk analisis univariat ini tergantung dari jenis datanya.. Analisis univariat bertujuan menggambarkan distribusi dan persentase dari variabel data.

b. Analisa Bivariat untuk melihat pengaruh variabel independent (edukasi atau pendidikan kesehatan) terhadap variabel dependen dengan menggunakan uji $\mathrm{T}$ berpasangan (Paired Sample) yang digunakan untuk menguji mean antara dua kelompok data yang dependen.

\section{HASIL PENELITIAN}

\section{Karakterisitik Responden}

Tabel 4.1 Distribusi Frekuensi Responden

Berdasarkan Umur, Jenis Kelamin, Suku, Agama, Pendidikan terakhir, Pekerjaan, dan Status Hubungan dengan Klien di RSUP H. Adam Malik Medan Tahun 2019

\begin{tabular}{ccc}
\hline Karakteristik & Frekuensi & \% \\
\hline Umur & & \\
$22-31$ & 13 & 13,0 \\
$32-41$ & 15 & 35.7 \\
$42-51$ & 8 & 19.0 \\
$52-61$ & 5 & 11.9 \\
$62-71$ & 1 & 2.4 \\
\hline Total & $\mathbf{4 2}$ & $\mathbf{1 0 0 . 0}$ \\
\hline Jenis Kelamin & & \\
Laki-laki & 7 & 16.7 \\
Perempuan & 35 & 83.3 \\
\hline Total & $\mathbf{4 2}$ & $\mathbf{1 0 0 . 0}$ \\
\hline Suku & & \\
Batak & 19 & 45.2 \\
Minang & 1 & 2.4 \\
Jawa & 18 & 42.9 \\
Melayu & 2 & 4.8 \\
Lain-lain & 2 & 4.8 \\
\hline Total & $\mathbf{4 2}$ & $\mathbf{1 0 0 . 0}$ \\
\hline Agama & &
\end{tabular}


Vol. 16 No. 3 September - Desember 2021

\begin{tabular}{ccc} 
Islam & 26 & 61.9 \\
Protestan & 16 & 38.1 \\
\hline Total & $\mathbf{4 2}$ & $\mathbf{1 0 0 . 0}$ \\
\hline Pendidikan & & \\
Terakhir & & \\
SD & 3 & 7.1 \\
SMP & 13 & 31.0 \\
SMA & 25 & 59.5 \\
SARJANA & 1 & 2.4 \\
\hline Total & $\mathbf{4 2}$ & $\mathbf{1 0 0 . 0}$ \\
\hline
\end{tabular}

Uji normalitas data digunakan untuk mengetahui normal atau tidaknya sebaran data dari suatu variabel.

Tabel 4.2 Hasil Uji Normalitas Data dengan

Shapiro-Wilk Kemampuan Responden dalam

Perawatan Stoma pada pasien Kolostomi di RSUP

H. Adam Malik Medan Tahun 2019 Sebelum Diberi Edukasi

\begin{tabular}{ccc}
\hline Domain & Df & Sig \\
\hline Pre Test & 42 & $0,000(\mathrm{TN})$ \\
Pengetahuan & & $0,000(\mathrm{TN})$ \\
Pre Test Tindakan & 42 & $0,000(\mathrm{TN})$ \\
$\begin{array}{c}\text { Pre Test } \\
\text { Kemampuan }\end{array}$ & 42 & \\
\hline
\end{tabular}

TN: Tidak Normal, N: Normal

Berdasarkan Tabel 4.2 diatas menunjukkan Uji normalitas dengan menggunakan Shapiro Wilk Test $(\mathrm{n}=<50)$ bahwa kemampuan keluarga dalam perawatan stoma sebelum diberi edukasi merupakan data yang tidak berdistribusi normal $(\mathrm{p}<0,05)$ sehingga dianalisis menggunakan uji Willcoxon untuk melihat perbedaan kemampuan keluarga dalam perawatan stoma sebelum dan setelah pemberian edukasi.

Tabel 4.3 Hasil Uji Normalitas Data dengan

Shapiro-Wilk Kemampuan Responden dalam Perawatan Stoma pada pasien Kolostomi di RSUP H. Adam Malik Medan Tahun 2021 Setelah Diberi klien. Hasil penelitian, pada umumnya mayoritas responden berumur 32-41 tahunsebanyak 15 (35,7\%) responden, mayoritas responden berjenis kelamin perempuan sebanyak $35(83,3 \%)$ responden. Pada umumnya responden beragama Islam sebanyak 26 $(61,9 \%)$ responden dan sebagian besar bersuku batak sebanyak $19(45,2 \%)$ responden meliputi batak toba, batak karo dan batak mandailing. Berdasarkan latar belakang pendidikan terakhir, mayoritas responden memiliki jenjang pendidikan SMA sebanyak 25 $(59,5 \%)$ responden. Berdasarkan pekerjaan, mayoritas responden bekerja sebagai petani sebanyak 11 (26.2\%) responden. Dan saat dilakukan penelitian, mayoritas responden yang ditemui mempunyai hubungan dengan klien sebagai istri sebanyak 17 (40.5\%) responden.

2. Hasil Uji Normalitas Data

Edukasi

\begin{tabular}{ccc}
\hline Domain & Df & Sig \\
\hline $\begin{array}{c}\text { Post Test } \\
\text { Pengetahuan }\end{array}$ & 42 & $0,000(\mathrm{TN})$ \\
Post Test Tindakan & 42 & $0,000(\mathrm{TN})$ \\
$\begin{array}{c}\text { Post Test } \\
\text { Kemampuan }\end{array}$ & 42 & $0,000(\mathrm{TN})$ \\
\hline
\end{tabular}

TN: Tidak Normal, N: Normal

Berdasarkan Tabel 4.3 diatas menunjukkan Uji normalitas dengan menggunakan Shapiro Wilk Test $(\mathrm{n}=<50)$ bahwa kemampuan keluarga dalam perawatan stoma setelah diberi edukasi merupakan data yang tidak berdistribusi normal $(\mathrm{p}<0,05)$ sehingga dianalisis menggunakan uji Willcoxon untuk melihat perbedaan kemampuan keluarga dalam perawatan stoma sebelum dan setelah pemberian edukasi.

Kemampuan responden dalam perawatan stoma sebelum diberi edukasi (pre test). 
Tabel 4.4 Distribusi Frekuensi Kemampuan Responden dalam Perawatan Stoma pada pasien Kolostomi di RSUP H. Adam Malik Medan Tahun 2021 Sebelum Diberi Edukasi $(n=42)$

\begin{tabular}{cccccc}
\hline $\begin{array}{c}\text { Parameter } \\
\text { Kemampuan }\end{array}$ & Frekuensi & Persentase(\%) & Mean & Sd & Min-Maks \\
\hline Kurang mampu & 23 & 54,8 & 2,45 & 0,504 & $2-3$ \\
Mampu & 19 & 45,2 & 2,45 & 0,504 & $2-3$ \\
\hline Total & $\mathbf{4 2}$ & $\mathbf{1 0 0 , 0}$ & & & \\
\hline
\end{tabular}

Berdasarkan Tabel 4.4 diatas menunjukkan kemampuan keluarga sebelum intervensi (pre test)bahwa mayoritas responden memiliki kemampuan kurang dalam perawatan stoma sebanyak 23 orang $(54,8 \%)$ dan responden yang mampu merawat stoma sebanyak 19 orang $(45,2 \%)$ dengan nilai rata-rata kemampuan 2,45, sebaran data $(\mathrm{SD})=0,504$ dan rentang 2 sampai 3.

Kemampuan responden dalam perawatan stoma setelah diberi edukasi (post test.)

Tabel 4.5 Distribusi Frekuensi Kemampuan Responden dalam Perawatan Stoma pada pasien Kolostomi di RSUP H. Adam Malik Medan Tahun 2021 Setelah Diberi Edukasi (n=42)

\begin{tabular}{cccccc}
\hline $\begin{array}{c}\text { Parameter } \\
\text { Kemampuan }\end{array}$ & Frekuensi & Persentase(\%) & Mean & Sd & Min-Maks \\
\hline Mampu & 42 & 100,0 & 3,00 & 0,000 & $3-3$ \\
\hline
\end{tabular}

Berdasarkan Tabel 4.5 diatas menunjukkan setelah intervensi (post test) bahwa responden sebanyak 42 orang $(100 \%)$ memiliki kemampuan dalam perawatan stoma dengan nilai rata-rata kemampuan 3,00, sebaran data $(\mathrm{SD})=$ 0,000 dan rentang 3 sampai 3.

Analisis Perbedaan Kemampuan Responden dalam Perawatan stoma Sebelum dan Setelah Pemberian Edukasi pada Pasien Kolostomi

Tabel 4.6 Hasil uji Willcoxon untuk Perbedaan Kemampuan Responden dalam Perawatan Stoma pada pasien Kolostomi di RSUP H. Adam Malik Medan Tahun 2021 Sebelum dan SetelahPemberian Edukasi

\begin{tabular}{cclcccc}
\hline Kelompok & Kemampuan & Mean & Median & Min-Maks & SD & P Value \\
\hline Intervensi & Sebelum & 2,45 & 2,00 & $2-3$ & 0,504 & 0,000 \\
& Setelah & 3,00 & 3,00 & $3-3$ & 0,000 & 0,000 \\
\hline
\end{tabular}

Setelah dilakukan uji Willcoxon Signed Rank Test secara keseluruhan pada responden sebelum dan setelah pemberian edukasi, diperoleh. hasil median sebelum intervensi adalah 2,00 dan rentang 2 sampai 3, sedangkan hasil median setelah intervensi adalah 3,00 dan rentang 3 sampai 3. Diperoleh nilai significancy $(p)=0,000(p<0,05)$. Dari adanya perbedaan nilai median dan probabilitas $(\mathrm{p})<0,05$ dapat disimpulkan bahwa Ha diterima.

\section{PEMBAHASAN PENELITIAN}

Kemampuan keluarga dalam perawatan stoma pada pasien yang mengalami kolostomi sebelum diberi edukasi (pre test).

Hasil penelitian kemampuan keluarga dalam perawatan stoma pada pasien yang mengalami kolostomi sebelum intervensi (pre test) menunjukkan bahwa mayoritas responden memiliki rata-rata nilai kemampuan 2,45 $(\mathrm{SD}=0,504)$ dimana mayoritas responden memiliki kemampuan kurang dalam perawatan stoma sebanyak 23 orang $(54,8 \%)$ dan responden yang mampu merawat stoma sebanyak 19 orang $(45,2 \%)$. Penelitian ini sejalan dengan penelitian yang dilakukan oleh Santy Nainggolan (2011) bahwa mayoritas responden yang berjumlah 14 orang (93\%) dari 15 orang responden memiliki kemampuan kurang dalam perawatan stoma sebelum diberikan edukasi.

Menurut Nurhidayah, (2009) ketidakmampuan melakukan suatu tindakan paling sering disebabkan oleh kurangnya terpapar pengetahuan tentang cara melakukan tindakan tersebut (yang dimaksud disini perawatan stoma), atau merupakan akibat kurang atau sulitnya memperoleh sarana untuk melakukan tindakan tersebut. Menurut peneliti didapatkan lebih banyak keluarga yang mempunyai kemampuan kurang dibanding keluarga yang mampu dalam perawatan stoma dikarenakan keluarga kurang terpapar informasi dan keluarga yang tidak ingin memiliki rasa ingin tahu yang besar.

Menurut Friedman (dalam Setiawan \& Dermawan, 2008), salah satu fungsi keluarga adalah 
fungsi pemenuhan (perawatan/pemeliharaan) kesehatan yang merupakan fungsi keluarga untuk mencegah terjadinya masalah kesehatan dan merawat anggota keluarga yang mengalami masalah kesehatan. Hal ini berarti, karena kemampuan keluarga kurang mampu dalam merawat stoma pasien yang mengalami kolostomi sehingga penting sekali pemberian edukasi disini untuk meningkatkan kemampuan keluarga dalam perawatan stoma.Keluarga yang sangat berperan harus diajarkan bagaimana cara mengelola kolostomi sejak awal pembentukan yaitu ketika mereka masih di rumah sakit sehingga ketika sudah meninggalkan rumah sakit keluarga sudah mampu melakukan perawatan kolostomi secara mandiri (Burch, 2013).

Kemampuan keluarga dalam perawatan stoma pada pasien yang mengalami kolostomi setelah diberi edukasi (post test)

Hasil penelitian kemampuan keluarga dalam perawatan stoma pada pasien yang mengalami kolostomi setelah intervensi (post test) menunjukkan bahwa responden sebanyak 42 orang (100\%) memiliki kemampuan dalam perawatan stoma pada pasien yang mengalami kolostomi. Dengan rata-rata nilai kemampuan 3,00, $(\mathrm{SD}=0,000)$. Penelitian ini sejalan dengan penelitian yang dilakukan oleh Santy Nainggolan (2011) bahwa 100\% (15 orang) responden memiliki kemampuan dalam perawatan stoma setelah diberikan edukasi.

Berkembangnya kemampuan seseorang terjadi melalui tahapan tertentu, yang dimulai dari pembentukan pengetahuan, sikap, sampai dimilikinya keterampilan baru (Suliha et al. 2001). Salah satu cara untuk meningkatkan pengetahuan keluarga adalah dengan pemberian edukasi. Edukasi keluarga merupakan bagian dari asuhan keperawatan dengan memberikan pendidikan kesehatan yang terintegrasi yang berpusat pada masalah pasien (Potter et al. 2013). Edukasi merupakan penambahan pengetahuan dan kemampuan seseorang melalui teknik praktik belajar atau instruksi, dengan tujuan untuk mengingat fakta atau kondisi nyata, dengan cara memberi dorongan terhadap pengarahan diri (self direction), aktif memberikan informasi-informasi atau ide baru (Craven \& Hirnle, 1996 dalam Suliha, dkk, 2002).

Menurut peneliti perubahan kemampuan keluarga terjadi setelah pemberian edukasi kepada keluarga karena fungsi dari pemberian edukasi dapat meningkatkan pengetahuan dan kemampuan seseorang yang dari tidak tahu menjadi tahu. Ketika tercapainya pengetahuan keluarga maka keluarga mampu untuk melakukannya. Peneliti melakukan pendekatan kepada keluarga yang mana keluarga sangat berperan penting dan berrtanggung jawab untuk memenuhi kebutuhan anggota keluarga yang sedang sakit.. Pemberian edukasi melalui media leaflet dan melakukan tindakan prosedur perawatan stoma dimulai dari penyediaan alat dan tindakannya selama \pm 15 menit.

\section{Perbedaan kemampuan keluarga dalam perawatanstoma pada pasien sebelum dan setelah pemberian edukasi.}

Hasil penelitian menunjukkan bahwa pemberian edukasi mempunyai pengaruh terhadap kemampuan keluarga dalam perawatan stoma pada pasien yang mengalami kolostomi. Hal ini dapat dilihat dari hasil uji statistik, dimana nilai $\mathrm{p}<0,05$ yaitu $\mathrm{p}=0.000$. Ha diterima dan ho ditolak didalam penelitian ini artinya edukasi berpengaruh dalam peningkatan kemampuan keluarga dalam perawatan stoma.

Menurut peneliti perubahan kemampuan merawat stoma disebabkan adanya pemberian edukasi berupa informasi melalui media leaflet dan melakukan prosedur tindakan perawatan kolostomi yang tepat. Edukasi ini diberikan selama \pm 15 menit. Dengan adanya edukasi tentang perawatan stoma ini, keluarga mengerti informasi tentang kolostomi atau stoma, perawatan kolostomi atau stoma, dan efek samping atau komplikasi yang terjadi jika stoma tidak dirawat dengan tepat. Hal ini tergambar dari nilai mean (nilai rata-rata) kemampuan responden dalam merawat stoma pasien kolostomi sebelum diberi edukasi yaitu 2,45 dengan $\mathrm{SD}=.504$, yang menunjukkan bahwa kemampuan keluarga kurang dalam merawat stoma.

Sedangkan setelah diberi edukasi kemampuan keluarga merawat stoma meningkat menjadi rata-rata 3,00 dengan $\mathrm{SD}=.000$, dan ini menunjukkan mereka sudah mampu merawat stoma anggota keluarganya. WHO (1954 dalam Notoatmojo, 1997) menyatakan salah satu tujuan dari edukasi yaitu menolong individu agar mampu secara mandiri atau berkelompok mengadakan kegiatan untuk mencapai tujuan hidup sehat. Purwanto (1999) mengatakan bahwa perubahan perilaku seseorang dapat terbentuk karena berbagai 
pengaruh atau rangsangan berupa pengetahuan, sikap, pengalaman, keyakinan, sosial, dan budaya.

Edukasi merupakan penambahan pengetahuan dan kemampuan seseorang melalui teknik praktik belajar atau instruksi, dengan tujuan untuk mengingat fakta atau kondisi nyata, dengan cara memberi dorongan terhadap pengarahan diri (self direction), aktif memberikan informasi-informasi atau ide baru (Craven \& Hirnle, 1996 dalam Suliha, dkk, 2002). Suliha, dkk (2002) juga menegaskan bahwa edukasi merupakan proses belajar dari individu, kelompok, atau masyarakat dari tidak tahu tentang nilai kesehatan menjadi tahu, dan dari yang tidak mampu mengatasi masalah kesehatan sendiri menjadi mampu mengatasi masalah kesehatan sendiri secara mandiri.

Dengan pemberian edukasi yang efektif yang diberikan perawat diharapkan dapat berpengaruh terhadap kemampuan keluarga dalam perawatan stoma sehingga dapat menjaga kesehatan dan meningkatkan kenyamanan pasien kolostomi sehingga terhindar dari komplikasi yang dapat memperparah keadaan kondisi pasien. Kebanyakan individu sepakat bahwa keluarga yang sedang merawat keluarganya yang mengalami kolostomi memerlukan program pendidikan yang komprehensif dan tepat untuk mempersiapkan mereka berperan dan bertanggung jawab menjaga dan merawat keluarganya.

\section{KESIMPULAN}

Berdasarkan hasil penelitian dan uraian pembahasan tentang pengaruh edukasi terhadap kemampuan keluarga dalam perawatan stoma pada pasien yang mengalami kolostomi di RSUP H. Adam Malik Medan Tahun 2021 yang dilakukan melalui pembagian kuesioner pengetahuan dan lembar observasi penyediaan alat dan tindakan prosedur perawatan stoma dapat disimpulkan bahwa:

1. Edukasi sangat mempengaruhi kemampuan keluarga dalam perawatan stoma. Ini dibuktikan dari hasil penelitian ini bahwa kemampuan keluarga sebelum dilakukan intervensi (pre test) menunjukkan bahwa mayoritas responden memiliki kemampuan yang kurang dalam perawatan stoma sedangkan setelah intervensi (post test) menunjukkan bahwa seluruh responden mampu melakukan perawatan stoma pada keluarganya yang mengalami kolostomi.
2. Keluarga sangat berperan penting dan bertanggung jawab kepada anggota keluarganya yang sakit atas pemeliharaan kesehatan sampai pada perawatan kolostomi .Oleh karena itu keluarga memerlukan pengetahuan untuk mampu melakukannya. Pemberian edukasi kepada keluargalah yang menjadi jawabannya sesuai hasil analisis Willcoxon Sign Rank Test, diperoleh nilai significancy $(\mathrm{p})=0,000$ ( $\mathrm{p}$ value $<0,05)$ artinya Ha diterima didalam penelitian ini bahwa edukasi berpengaruh dalam peningkatan kemampuan keluarga dalam perawatan stoma atau ditemukan perbedaan antara kemampuan responden sebelum dan sesudah diberikan edukasi, dimana terjadi peningkatan kemampuan dalam perawatan stoma dibandingkan sebelum diberikan edukasi.

\section{SARAN}

Berdasarkan kesimpulan yang ditarik dari hasil analisa data, maka penulis mencoba memberikan rekomendasi sebagai berikut :

1. Bagi Perawat di ruang rawat inap dan yang bertugas di Poliklinik Penyakit Dalam RSUP H. Adam Malik Medan sebagai care provider perawat juga sebagai educator, oleh sebab itu penting sekali memberikan edukasi kepada keluarga dan pasien tentang perawatan kolostomi sehingga nantinya keluarga mampu dalam perawatan kolostomi dari segi pengetahuan maupun tindakan merawat keluarganya yang mengalami kolostomi secara mandiri sepulangnya kerumah.

2. Bagi Pendidikan Poltekkes Kemenkes Medan agar memfasilitasi referensi buku dengan menambah koleksi buku terbaru agar menunjang referensi peneliti sehingga menjadi salah satu skripsi yang baik dengan sumber-sumber yang up to date.

3. Bagi peneliti diiharapkan dapat meneliti dan mengembangkan pengaruh edukasi terhadap kemampuan keluarga dalam perawatan stoma

4. Bagi peneliti selanjutnya dapat memanagemen waktu penelitian dan memonitoring atau melakukan home care yang berfokus pada peningkatan kemampuan pasien dan mengevaluasi kemampuan keluarga dalam membantu pasien mencapai self care-nya. 


\section{DAFTAR PUSTAKA}

Abd,N. (2014). Buku Ajar Metodologi Penelitian Kesehatan. Edisi Kedua. Yogyakarta: Mulia Medika.

Arikunto, S. (2006). Prosedur Penelitian Suatu Pendekatan Praktik. Edisi Revisi VI. Jakarta: PT. Rineka Cipta.

Azwar, S. (2004). Metode Penelitian. Jakarta : Pustaka Pelajar.

Hegner, B.R, et al. (2003). Asisten Keperawatan: Suatu Pendekatan Proses Keperawatan. Edisi Keenam. Jakarta: EGC.

Herlufsen, et,al, (2006). Penderita Stoma Permanen. Jurnal Ilmiah Kesehatan.

Hidayat, A.A. (2007). Riset Keperawatan dan Teknik Penulisan Ilmiah. Edisi Kedua. Jakarta : Salemba Medika

Indonesia Ostomy Association/NIO, (2010). Kanker Kolorektal, Indonesia.

KBBI. (2005). Kamus Besar Bahasa Indonesia. Edisi ketiga. Jakarta: Balai Pustaka.

Kalibjan, (2013). Pengaruh edukasi terstruktur terhadap pengetahuan, sikap dan tindakan pasien dalam perawatan stoma di RSUP Dr. Djamil. Padang.

Lyon CC, et al, The Spectrum of Skin Disorders in Abdominal Stoma Patients. The British Journal Of Dermatology [Br J Dermatol]. 143 (6),

Manggarsari (2013). Penyakit Kanker Kolorektal. Edisi Kedua. Jakarta: Pustaka Pelajar.

Muwarni (2009). Keterampilan Dasar Praktek Klinik Lapangan. Yogyakarta: Fitramaya.

Myers, Celia. (1996). Stoma care nursing a patientcentred approach. London: Arnold.

Nainggolan,S. (2012) Pengaruh Pemberian Edukasi terhadap Kemampuan Keluarga yang memiliki anggota keluarga menggunakan Kolostomi di RSUP. H. Adam Malik Medan. Jurnal Kesehatan Ilmiah. Fakultas Keperawatan USU.
Notoatmodjo, S. (2012). Metodologi Penelitian. Jakarta: Rineka Cipta.

Nursalam. (2003). Konsep dan Penerapan Metodologi Penelitian Ilmu Keperawatan : Pedoman Skripsi, tesis dan Instrumen Penelitian Keperawatan. Jakarta : Salemba Medika.

Nyswander. (1999). Pendidikan dalam Keperawatan. Cetakan Pertama. Jakarta: EGC.

Piccinellil M, et al, (2009). Assessment of the prevalence and perception of skin problems in patients with permanent stoma. Dibuka tanggal 10 september 2011.

Politeknik Kesehatan Kemenkes Medan. (2015). Panduan Penyusunan Karya Tulis Ilmiah. Politeknik Kesehatan Kemenkes Medan.

Rakhmat, Ns. (2011). Pendidikan Kesehatan dalam Keperawatan. Cetakan Kedua. Yogyakarta: Nuha Medika.

Setiawati, S \& A. C. Dermawan. (2008). Proses Pembelajaran Dalam Pendidikan Kesehatan. Jakarta: TIM.

Setyorini \& Dyah, 2009. Pemilihan Kantong Kolostomi yang Tepat bagi Ostomate.

Siregar, C. T, et al, (2009). Buku Panduan dan Prosedur Penilaian Praktikum Laboratorium Keperawatan Medikal Bedah. Medan.

Siegel et al. 2015. Kanker Kolorektal. Edisi Ketiga. Semarang: Penerbit Alfabeta.

Sodokin. (2013). Asuhan Keperawatan Anak Gangguan Sistem Gasrointestinal dan Hepatobiler. Edisi Pertama. Jakarta: Salemba Medika.

Suratun \& Lusianah, (2018). Asuhan Keperawatan Klien Gangguan Sistem Gastrointestinal. Edisi Kedua., Jakarta Timur: Trans Info Media.

Susilo,R. (2017). Pendidikan Kesehatan dalam Keperawatan. Edisi Kedua. Yogyakarta: Nuha Medika.

Sugiyono. (2017). Metodo Penelitian Kuantitatif,Kualitatif dan R \& D. Bandung: CV Alfabeta. 
Suriadi. (2018). Perawatan Luka. Edisi 1. Tangerang: Bina Rupa Aksara.

Sjamsuhidajat, Jong. (1997). Buku Ajar Ilmu Bedah. Ed. Revisi, Jakarta: EGC.

Smeltzer, Bare. (2002). Buku Ajar Keperawatan Bedah Brunner dan Suddarth. Volume 2, Jakarta: EGC.

Stuart. (1968). Pendidikan dalam Keperawatan. Cetakan 1. Jakarta: EGC

Suhartono, S. (2005). Filsafat Ilmu Pengetahuan. Jogjakarta: Ar-Ruzz Media

Sudiharto. (2007). Asuhan Keperawatan Keluarga. Jakarta: EGC

Sukardi. (2009). Metodologi Penelitian Pendidikan : Kompetensi dan Praktiknya. Jakarta : Bumi Aksara.
Suliha, U, et al, (2001). Pendidikan Kesehatan dalam Keperawatan. Jakarta: EGC.

Suprajitno (2004). Asuhan keperawatan Keluarga: Aplikasi dalam Praktik. Jakarta: EGC.

Tarigan R, et al, (2012). Pengujian reliabilitas dan validitas Kuesioner dan lembar Observasi. Medan: Fakultas Keperawatan USU.

Wahyuni, A.S . (2008). Statistika Kedokteran : disertai aplikasi dengan SPSS. Jakarta : ISBN

WHO (2008). Pedoman Perawatan Pasien. Jakarta: EGC.

Wong, D.L \& hockenberry, M.J. (2009). Wong's Nursing Care of Infant and Children. Jakarta: EGC. 